\title{
But could they tell right from wrong? Evolution, moral responsibility and human distinctiveness
}

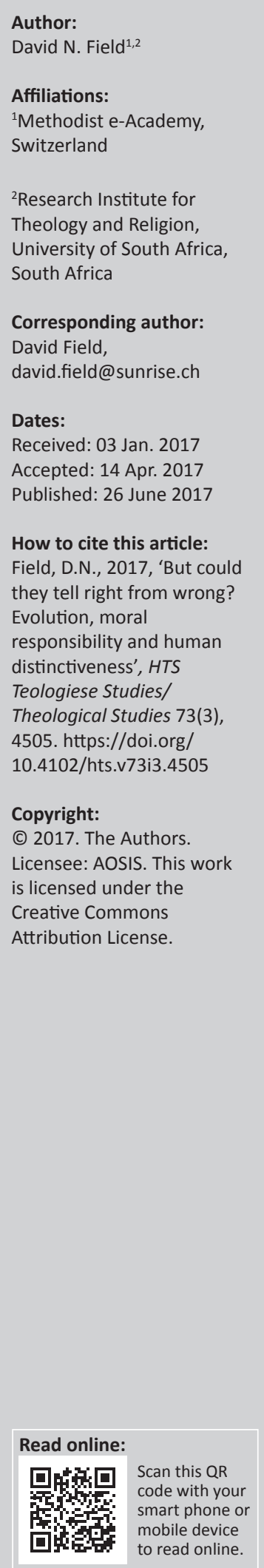

This article takes as its point of departure the public interest aroused by the discovery of Homo naledi and the debate about the possibility that $H$. naledi buried their dead. If they buried their dead, did $H$. naledi have an awareness of moral responsibility? We have no basis in the fossil remains of $H$. naledi or other hominids for determining when and how the awareness of moral responsibility evolved. The article provides a brief summary of the evidence for the evolution of morality based on research into the behaviour of other primates and then argues that human moral consciousness is qualitatively distinct from this but can still be understood to be the product of evolution. In the final section the article draws on ideas from the theologies of John Wesley and Dietrich Bonhoeffer to provide a theological interpretation of this evolution of moral consciousness.

\section{Introduction}

During 2013 and 2014 scientists descended into a deep inaccessible cave in the Rising Star Cave system in Cradle of Humankind Heritage sight in Gauteng, South Africa, and returned to the surface with fossils of an early hominid. As the researchers examined the fossils they were surprised not only by the number of specimens found in the deep darkness of the cave, but that there appeared to be only one very restricted entrance. The fossils themselves showed no sign of the consequences of being the victims of carnivorous animals. So the mystery of Homo naledi was born. How did the fossils get there? Or more accurately how did the bodies get there? The solution posed by some of the researchers was that they must have been carried there after death by their living relatives. If so had $H$. naledi developed the skill to use fire - for how would they have found their way through the darkness? But perhaps more intriguingly was the idea that $H$. naledi buried their dead. Prior to the discovery of $H$. naledi the clearest evidence of ritual burial practices has been found in the excavation of Neanderthal remains (Fuentes 2009:92). If H. naledi did bury their dead, what is the significance of this for our understanding of $H$. naledi? Perhaps more significantly what is its significance for our human self-understanding? Was this a religious act? Did it mean they wanted to protect the bodies from predators? If so why? Was it because the value they attached to their fellows? Does this mean they were capable of what we might call ethical responsibility? Whether or not the evidence warrants the conclusion that $H$. naledi buried their dead remains a matter of debate. The conclusions we can draw from such a practice lie very much in the realm of speculation. Further, the evolutionary relationship between $H$. naledi and other hominids in general and Homo sapiens in particular remains a matter of further research and debate. In part this relates to the dating; if $H$. naledi is to be dated at about two to two and a half million years ago (Thackeray 2015) then it is possible that $H$. naledi may be at transitional species in the early development of the genus Homo. If however it is to be dated around 900000 years ago (Dembo, Radovčić \& Garvin 2016) then H. naledi would have been a contemporary of early H. sapiens. ${ }^{1}$

The discovery of $H$. naledi and its mysterious potential to enlighten our understanding of the past has sparked considerable curiosity beyond the scientific community. Let us in our imagination leave the dark caves in the Africa veld and travel to another place and another time. The time is a few minutes before 4 o'clock in the morning on a Monday morning; the place is Basel, Switzerland. The streets are thronged with people from near and far. The church bells begin to ring. The city is plunged into darkness - as all electrical lighting is turned off. All is not dark; there are small lights on masks worn by some of the people and behind the masked groups are larger wheeled lanterns. The clock strikes four, and the silence is broken with cries of: 'Achtung! Morgestraich, vorwärts marsch!' [Attention, the stroke of morning, forward march]. The night is filled with sounds of 
drums and piccolos. This marks the beginning of 3 days of costumed bands of parading through the streets. It all comes to a sudden silence on Thursday morning at $4 \mathrm{o}^{\prime}$ clock. This is the Basler Fasnacht, which starts every year on the Monday after Ash Wednesday.

What has all of this to do with fossils left lying in a cave outside Johannesburg? Most of the groups of costumed marchers who parade are not just random groups of people. They are members of Cliquen [cliques]; these associations have existed for decades, which meet regularly together to practise their music and most importantly to plan a theme and with it the associated costumes and lantern. In most cases the theme is a satirical comment on events or movements of the past year. In 2016 the d'Querschleeger clique chose as its theme: Mensch, Naledi! This can be directly translated as 'Human, Naledi!' However, the German word Mensch is also used, in everyday speech, as an expression of surprise, astonishment, shock or admiration. The title of the theme thus conveys a double meaning. On the one hand it expresses fascination and astonishment at the discovery of $H$. naledi. On the other it raises the fascinating and unanswered question of the nature of relationship between contemporary humanity and $H$. naledi.

This question was taken up in the decorations on their lantern. ${ }^{2}$ The first panel displayed a typical picture of an evolutionary tree with $H$. naledi at the centre and various depictions of the diversity of humanity were portrayed in the branches. Despite our present ignorance as to the place of $H$. naled $i$ within the evolutionary development of the hominids, this picture perhaps portrays the longing for an evolutionary Adam, a common ancestor that provides a point of unity in the midst of the diversity of humanity. This unity has become more significant as we are confronted with conflict, terror and war. The second panel portrays a stereotypical picture of early cave-dwelling hominids with the inscription in the Basel German dialect. This must be understood against the intense football rivalry between the cities of Basel and Zürich with its associated hooliganism. This, in the opinion of staunch Basel supporters, is instigated by the uncivilised Zürich fans. The inscription reads 'Sy haige schyyns ganz wyyt unde neiy art Ziircher gfunde', which when translated means: 'It seems that they have found very far down under a new type of Zürcher' - that is uncivilised hooligans. The implicit presupposition is that early hominids were savages with no moral awareness. The third panel displayed a picture of the evolutionary future on the one hand with planets and space ships, styled after the USS Enterprise of Star Trek, and on the other hand in the centre is a mushroom cloud made up of skulls. Posing the question of are we at all ethically superior to the supposed savagery of $H$. naledi?

Perhaps the potential significance of the theory that $H$. naledi buried their dead lies here. Is this the first glimmers of what

2.Pictures of the lantern and the costumed marchers can be found on the d'Querschleeger website at: http://www.querschleeger.ch/wp/index.php/ nggallery/fasnacht-2016/fasnacht-2016-mensch-naledi?page_id=90. Viewed 17 December 2016. we might describe as ethical awareness or moral responsibility? Given the limited data we now have and the uncertainties about its interpretation means that the answer to this question lies in the realm of speculation. However, it raises intriguing and perhaps disturbing questions about the origins and distinctiveness of human morality. To address these questions we need to move beyond $H$. naledi. Yet the fossil record leaves very little indication of when or how a sense of moral responsibility emerged. What we do know is that:

... sometime in our past our ancestors were part of a remarkable
emergence into self-awareness, with an increasing capacity for
consciousness, the possibility for moral responsibility, and the
yearning and capacity for aesthetic and religious fulfilment. (Van
Huysteen 2006:37)

The capacity for moral responsibility is, as Van Huysteen proposes, a distinguishing characteristic of humanity, but the questions of how human behaviour patterns evolved and how we came to evaluate some as good and some as evil, and the significance of this awareness, remain. An alternative way of approaching the question that seeks to overcome the relative paucity of the archaeological evidence is through the observation of the behaviour of our nearest evolutionary relatives - chimpanzees and bonobos.

\section{Primate behaviour and the origins of morality}

Frans de Waal has argued that bonobos and chimpanzees demonstrate behaviour that can at the least be described as the precursors to behaviour that humans describe as moral. ${ }^{3}$ Observations of chimpanzees and other apes both in captivity have proved to be provocative both negatively and positively. It is known, for example, that bands of chimpanzee males will engage in violent and often deadly conflicts with neighbouring bands. The attacks on the neighbours demonstrate levels of communication between the participants and some forms of planning. In some cases, the aim appears to be to protect territory and in others to expand access to resources and to obtain new females for the band (Goodall 2010:114-129; Morris 2015:228-232). All of these make some genetic sense - the need to expand access to resources ensures the survival of the band, and bringing new females into the group counters the effects of interbreeding. During various stages of human history, not the least in the past decades we see similar violent human behaviour both on smaller and larger scales. While chimpanzee behaviour might cause some disgust we do not evaluate it morally. When humans behave in the same way significant sections of the human population reject it as morally repulsive.

Apes will also engage in other activity that in a human context would be regarded as morally questionable. These include malevolence and deception (De Waal 1998:55), ${ }_{1}^{4}$ selfishness and

3.This is argued extensively in the work of De Waal (1996; 1998; 2013). See also the critical dialogue with De Waal in the study of Macedo and Ober (2016).

4.De Waal also describes incidents of deception in his research as illustrations of how apes react with sympathy $(1996: 44)$ or empathy $(2006: 30)$ to the supposed distress of another, but he does not comment on its deceptive character. 
greed (De Waal 1998:61), temper tantrums (De Waal 1998:69), violent power struggles (De Waal 1998:77-135) and the abandonment of babies (De Waal 1998:71). To what extent early humans engaged in similar behaviour is a matter of debate.

In contrast we also find behaviour patterns among chimpanzees, bonobos and other apes, which demonstrate levels of sympathy (De Waal 1996:40-88), empathy (De Waal 2006:21-42), gratitude (De Waal 2006:42-44), fairness (De Waal 2006:44-49) and even altruism. Members of a chimpanzee band will care for an injured member of the band even when it exposes the group to considerable danger. Groups will also socially enforce behaviour through punishing those who act contrary to the interests of the group. It is highly likely that the ancestors of contemporary humans had similar behaviour patterns within their groups.

It is worth noting that bonobos in contrast to Chimpanzees do not engage in violent behaviour. This difference in behaviour might be related to chimpanzees having a strongly patriarchal social structure, which results in violent competition between males. Bonobos, in contrast, have a matriarchal social structure, which is characterised by less rivalry. Were the behaviour patterns of the common ancestors of hominids, bonobos and chimpanzees more like bonobos or more like chimpanzees? It is more complex in that Bonobos and Chimpanzees share a common ancestor who lived after the emergence of the ancestor of the hominids. Humans have some genes in common with bonobos that they do not have in common with chimpanzees, and some genes in common with chimpanzees that they do not have in common with bonobos (De Waal 2013:81). Hence it is possible that our common ancestor demonstrated a mixture of behaviour patterns. Fossil evidence of violent death of some early humans suggests that inter human violence was a characteristic of some or our hominid ancestors (Zollikofer et al. 2002). However, given that the populations were reasonably small and the possibilities of encounters with other groups relatively rare, it is probable that the cooperative behaviour would have been the dominant characteristic of their behaviour. Evidence for greater levels of violence occurs as the populations increase and early humans begin to live together in larger groups. Viewed in the light of the behaviour patterns of chimpanzees and bonobos, elements of human behaviour that we evaluate morally as both negatively and positively appear to have their roots in our evolutionary past. In particular, they reflect the social behaviour required by and shaped by living in small roaming bands.

\section{Human distinctiveness}

Wentzel van Huysteen (2006) argues that:

... one of the most central and fundamental motivations for human actions is to act out and sustain moral order, which helps constitute, directs, and makes significant human life itself. Human Persons nearly universally live in social worlds that are thickly webbed with moral assumptions, beliefs, commitments, and obligations. The relational ties that hold humans together are glued with moral premises, convictions, and obligations. (p. 289)
Human moral consciousness moves significantly beyond the proto-morality found in the behaviour of chimpanzees, bonobos and other non-human animals. I propose that this moral distinction includes at least five factors. These are clearly not the only characteristics of human moral consciousness, other factors could be added and moral consciousness could be described using different distinctions, but these also provide a potentially fruitful way of understanding human moral particularity. ${ }^{5}$

The first factor is moral intentionality. The second is communicable norms or rules. The third is self-conscious moral awareness and evaluation. The fourth is morally responsible decision-making. The fifth is the development of genuine altruism.

Human morality is not a simple reaction to a particular immediate situation; it entails a moral intentionality that extends beyond the immediate to encompass a broader perspective of the perceived good of the individual or group. It thus gives rise to moral values that transcend particular situations, which provide the basis for addressing related situations in other contexts.

This intentionality beyond a specific context is given concrete form in systems of codified norms or rules that are present in virtually all human societies. These moral codes guide people's conduct, are the foundations of moral evaluation and in some cases the basis for punishment or reward. The norms can be oral and or written and range from simple conventions to complex legal codes. They are communicated in various ways to the members of the society and they endure over time.

Human beings internalise moral codes and self-consciously evaluate their own behaviour in the context of these codes. The result is a kind of awareness not merely that something brings good or bad personal consequences, but that particular behaviour is right or wrong, good or evil regardless of the consequences. Hence, behaviour-judged good and right is to be pursued for its own sake, and behaviour-deemed wrong or evil is to be avoided even when there are no potential negative consequences.

Moral responsibility deepens and extends moral awareness as it involves taking responsibility for acting in complex situations where different moral norms compete with each other. Further, it entails the pursuit of what one determines is morally responsible even when there are negative consequences for oneself.

Forms of altruism can be found in primates and other animals where animals act for the good of other animals even at cost to themselves. In most cases this appears to be within the context of seeking the good of kin or wider groups and have some benefit for the actor. Human altruism goes beyond this

5. While the selection of these five factors is a personal proposal, it is based on the discussion that is found in De Waal (1996; 2013), Macedo and Ober (2016) and Van Huysteen (2006:289-292). 
in that it includes a genuine intention to seek the good of another even though the other has no relationship to one, and it has no benefits for the actor. In some cases, it includes spontaneity - a seemingly random act of kindness; in others it is a long-term sacrificial commitment to the well-being of another.

These five elements of human morality I would propose are not mere developments of the 'morality' we find in other animals; there is a qualitative step beyond ape 'morality'. Something new merges that is in continuity with this protomorality but is not simply a development of it. To argue that human morality is qualitatively distinct from that of other animals does not mean it does not have an evolutionary origin. Rather it forms part of the evolutionary emergence of culture, language and social structures. The concept of emergence refers to something new which comes into existence but which has its origins in pre-existing conditions and developments but cannot be reduced to the sum of or mere combination of these conditions and developments. The often complex interaction of factors gives rise to something new. Closely related to the concept of emergence is that of convergence. Convergence refers to the coming together of diverse and unrelated factors giving rise to a new development. Human distinctiveness in all its facets is best understood as an evolving uniqueness that emerged over time in response to the convergence of diverse factors, development, situations and challenges. A particularly significant factor is that this was not purely biological factors but is a result of the interaction of cultural and biological factors. These diverse biological and cultural evolutionary adaptations coalesced to produce a qualitative difference. ${ }^{6}$ The evolution of complex morality is probably particularly to be associated with development of symbolic thought, human self-reflection, larger social formations and increased interaction between different groups of humans. Symbolic thought enables reflection on abstract concepts, while increased social interaction within larger social formation requires common understandings of appropriate and inappropriate behaviour.

Importantly the five factors open the way for human beings to counter - to move against and beyond their evolutionary heritage in new directions towards communities and societies characterised by a deep concern for the well-being of others particularly those who suffer, who are powerless and excluded.

\section{Theological reflection}

The development of evolutionary approaches to human morality is often portrayed as scientific alternatives to religious explanations. If it is possible to explain morality by the process of evolution then there is no need to postulate a divine source of morality. There is no need for God to thunder 10 Commandments from Mt Sinai or to send prophets to instruct the people. Morality can be satisfactorily explained as a natural development. The primatologist Franz de Waal has argued for such a position in numerous publications, most comprehensively in The Bonobo and the Atheist: In Search of Humanism amongst the Primates (De Waal 2013). De Waal's argument is aimed at countering religious apologists who claim that religion is the necessary foundation for morality and that without it society would degenerate into moral chaos. He recognises the role religion plays in supporting a moral order society and that the forced removal of religion is not only impossible but impractical - he strongly critiques the efforts of militant atheists. He is rather proposing thesis that a humanistic ethic can be understood to emerge out of the evolutionary process. In The Bonobo and the Atheist he examines various dimensions of the proto-morality of primates giving particular attention to Bonobos to argue that the fundamental building blocks of human morality are to be found in nonhuman animals particularly those closely related to humanity. This emergence of morality is a multilayered development that includes genetic factors but goes beyond them in the evolution of primates as social animals. Practices that contribute to the harmony of the community have evolved to become the characteristic features of Bonobo society. Behaviour that runs counter to the harmony of the community is excluded. He argues that human moral consciousness emerges out of this as part of the development of human distinctiveness. This emergence precedes organised religion of any sort and occurred long before the rise of the major religions of today. The relationship between religion and morality is not that religion gave rise to morality but that, in part, religion took its present form in order to support already emerged moral ideas. Hence, morality does not come from without (that is from religion); while religion continues to play a role in promoting morality, it is not necessary for the establishment of moral societies. In places De Waal does recognise that religious morality sometime goes beyond the necessity of promoting communal harmony as, for example, in the parable of the Good Samaritan (De Waal 2013:141). De Waal's argument raises a number of important issues; unfortunately, it is weakened by two significant factors. One is his rather generic use of the concept of 'religion'; while recognising the variety of religious expressions, his focus is largely on a traditional understanding of Christianity. He does not deal with the variety of ways in which diverse religious traditions relate to morality. Even when dealing with Christianity his dialogue partners are largely popular conservative, expressions of Christianity rather than academic theological accounts of morality. Secondly, and more fundamentally, the result of this is that he operates with caricature of religious ethics and its relation to evolutionary theory. The result of this is that he sets up a false antithesis between religious morality and an evolutionary morality. His recognition that the parable of the Good Samaritan goes beyond evolved morality and his later affirmation of the need to develop a morality that addresses a global society (De Waal 2013:234) are suggestive of an alternative way of understanding the relationship between particular religious traditions and evolved morality. 
De Waal is not alone in viewing religious and evolutionary explanations to be competing alternatives and people must decide for one or the other. As he himself notes some conservative Christians, for example, would accept this challenge and reject the evolutionary approach. I would suggest that this too is a false dilemma based on deeply problematic understanding of the relationship between the divine and creation in which God is seen to be one being among other, the greatest Being perhaps. Such an approach places divine and creaturely causality in competition with each other. I want to suggest that insights from two very different theologians might indicate an alternative.

\section{John Wesley}

The leader of the 18th-century religious revival in Britain might seem an odd choice, and significant aspects of his theology would be counterproductive; there are some elements of his theology that are suggestive in this regard. Wesley read widely and had a deep interest in the scientific issues of his time (Maddox 2009:23-54).

John Wesley in contrast to many Christian thinkers of his day did not draw clear distinction between human beings and other animals. As a student at Oxford University he wrote a major presentation on the souls of animals. This has unfortunately been lost; however, judging from his later writings he would probably have argued that animals like humans have souls (Wesley 1985:437-450). Wesley's interpretation of the relationship between human beings and other animals is shaped by a traditional interpretation of the Genesis narratives as describing an original paradisiacal state in which humans and other animals enjoyed superior qualities. The fall into sin by humans had catastrophic effects for the other animal as well. He argued that prior to the fall animals, like humans, had the properties of 'self motion', 'understanding', 'will', 'liberty' and even the resemblance of 'moral goodness' (Wesley 1985:440-441); while these properties were affected by the fall, they were not completely destroyed. He further proposed that human behaviour was in some cases morally inferior to animals. Ultimately, he argued, animals would be resurrected with human beings in the eschatological new creation. While, obviously, having no knowledge of contemporary evolutionary theories, he argued that humans are part of a great chain of being. This chain of being is marked by gradual distinctions rather than unbridgeable gaps between the species. What set human beings apart from other animals was their capacity to relate to God and calling that God had given them: qualities that are deeply related to what we would describe as human self-consciousness as it is expressed in human moral distinctiveness leading to moral responsibility. What Wesley demonstrates is that there is no theological necessity for proposing a massive gap between human beings and other animals, a gap which must be bridged by the miraculous divine act.

The second element in Wesley's theology that is potentially helpful is his theology of divine grace. While Wesley often speaks of God's action in an interventionist way that implies an understanding of God as one being among others, his theology of grace describes God's action in another way as that which underlies and enables human being and action without determining it (Maddox 1984:7-22). God's grace is relational and usually engages human beings through created means. It is in the encounter with other people that we develop ethical virtues (Wesley 1984:533-534). While Wesley develops this understanding primarily in relation to his understanding of sanctification (Field 2015b:182-184), he argues that God's grace is present in all human beings. It is this presence of God's grace that gives all human beings moral awareness and moral ability - God inscribes deep within the human personality an understanding of morality that is summed up in the golden rule (Field 2015a:2-8). While Wesley does not discuss how God gives human beings moral awareness it is consistent with his theology of grace to argue that at least in part such awareness comes through interaction with other people. Equally important is Wesley's argument that God's grace enables human beings to overcome evil and live lives characterised by deep altruism. ${ }^{7}$

A third aspect of Wesley's theology is his understanding of divine law. As I noted above Wesley believed that God inscribes, as it were, the golden rule within the human person without reference to any particular religious knowledge this is for him natural law. For Wesley religious law stands in continuity with this natural law. It is the revealed unfolding of its significance in relation to the diverse relationships and structures of human society. The Sermon on the Mount is a particular intensification of the natural law with its focus on motives and attitudes, and with the rest of the teaching of Jesus extends its reach by focusing not only on the immediate community but on those who are alien and even enemies (Wesley 1985:4-19).

\section{Dietrich Bonhoeffer}

There are two aspects of Dietrich Bonhoeffer's theology that are helpful in developing a theological interpretation of the evolution of morality. The first is drawn from his early theology expressed in his doctoral dissertation Sanctorum Communio. In his dissertation Bonhoeffer develops an interpretation of God's revelation that counters both liberalism that reduces revelation to human insight and the theology of Karl Barth who postulated revelation as a dramatic Word from God encountering human beings from beyond. Bonhoeffer proposed rather that God encounters human beings through their encounter with other human beings. In each encounter with another human being the other places an ethical demand challenging the encountered one to act in responsible love. However, it was God who constituted the human other as an ethical demand. God is present behind and in the ethical demand of the other (Bonhoeffer 1998:34-57). While this takes place in a particular way in the church it was not limited to the church. Bonhoeffer's theology is particularly suggestive as it is a

7.Hill (2016) develops an important contemporary interpretation of Wesley's theology of God's gracious transformation of human persons that enables them to develop deep love for others in dialogue with socio-biology and evolutionary theory. 
reinterpretation of the traditional Lutheran theology of the law as God's ethical demand. God's ethical demand comes not through some dramatic revelatory event, but in the ordinary, everyday encounter with other human beings.

The second insight from Bonhoeffer comes from his prison writings, where he rejected all notions of God as the deus ex machina, the God who stepped in to the gaps to provide an explanation when all human explanations failed (Bonhoeffer 2010:450). Rather God is present in the midst of the world within the world that human beings can explain and interpret scientifically. Any attempt to use the proposition of divine activity to explain what cannot be explained by science will inevitably be overtaken by new scientific developments. Hence, divine causality must not to be understood on the same level as creaturely causality. They are not competing explanations for the same phenomena. To posit this is to engage in 'religion' which has no place in a 'world come of age'. When it is done 'God' is gradually forced out of the world. More profoundly for Bonhoeffer the God of the gaps is not the God revealed in Jesus Christ. God is present and active in the absence of the God of the gaps.

\section{Towards a theological account of moral evolution}

A theological account of the evolution of morality must take the contemporary scientific picture of the world with great seriousness and hence affirm the complex evolution of morality. With Bonhoeffer it will reject any understanding of a God of the gaps who intervenes to constitute human beings as distinctive creatures, and following Wesley it can affirm that the qualities often associated with human uniqueness are present in other animals. Human distinctiveness is thus an evolving distinctiveness that emerged over time as a consequence of variety of dynamic factors as proto-humans interacted with each other and with other creatures. This does not exclude the presence and activity of God but rather affirms that God's presence and activity is to be understood as standing beneath the evolutionary processes enabling the development of moral consciousness, and hence ethical responsibility through the encounter with others. It thus affirms, with Bonhoeffer, that the knowledge of God's moral norms comes through the encounter with others - though here developing it to include other animals and proto-humans.

Drawing on the insights of Wesley's theology of grace it will affirm that this is the means by which God works root moral awareness in the human person. This is not to affirm all dimensions of the evolution of human culture as the consequence of God's presence and activity. In keeping with Wesley's understanding of responsible grace, cultural development was the response of proto-humans and early humans to God's presence and activity through the human and proto-human other. Such responses included both negative and positive dimensions. From a Christian perspective the responses are to be evaluated by their conformity to God's most complete revelation in history in Jesus the Christ.
The theological account of moral evolution, with Wesley, proposes continuity between morality from within and morality from without. The morality from without is in a Christian context an intensification and expansion of what is already present in the morality within. Further it goes on to affirm the possibility moving beyond and against the negative evolutionary heritage and even beyond the positive heritage to embody in our lives the self-giving love revealed in the crucifixion of Jesus (Hill 2016:135-217). The church, as the people of the crucified One, is called to embody such love in its life and mission. Such a theology both affirms and transcends an evolutionary account of morality and the development of ethical consciousness by putting it in the context of God's presence and activity in the world and calling human beings to transcend their evolutionary heritage.

Did H. naledi know right and wrong? We simply cannot answer that question. Given the number and variety of fossils found and what we know of other primates we can postulate that $H$. naledi were social animals, whether or not they buried their dead. As social primates their communal behaviour would, in all likelihood, have displayed patterns of behaviour that sought to maintain the harmony of their community. They would have had a least a form of proto-morality. It was such a proto-morality that was one of the pre-conditions of the emergence of moral responsibility in H. sapiens. Such an affirmation is neither a threat to an understanding of human uniqueness understood as the product of emergence and convergence. While it may contradict popular religious accounts of morality it is compatible with a more sophisticated theological account of morality and of God's presence in creation. Such a theological account of moral evolution does not merely affirm the evolved morality but recognised that in the context of fast-changing cultural and social evolution humans need not only to transcend and counter the negative dimensions of the past and enhance and strengthen the positive dimension, but also to develop an understanding of morality that is both more intensive and more extensive, an understanding of morality that can be found within some religious accounts of morality.

\section{Acknowledgements Competing interests}

The author declares that he has no financial or personal relationships which may have inappropriately influenced him in writing this article.

\section{References}

Bonhoeffer, D., 1998, Sanctorum Communio: A theological study of the sociology of the Church, Dietrich Bonhoeffer works, vol. 1, Fortress Press, Minneapolis, MN.

Bonhoeffer, D., 2010, Letters and papers from prison, Dietrich Bonhoeffer works, vol. 8, Fortress Press, Minneapolis, MN.

Dembo, M., Radovčić, D., Garvin, H.M., Laird, M.F., Schroeder, L., Scott, J.E. et al., 2016, 'The evolutionary relationships and age of Homo naledi: An assessment using dated Bayesian phylogenetic methods', Journal of Human Evolution 97, 17-26. https://doi.org/10.1016/j.jhevol.2016.04.008

De Waal, F., 1996, Good natured: The origin of right and wrong in humans and other animals, Harvard University Press, Cambridge, MA. 
De Waal, F., 1998, Chimpanzee politics: Power and sex among apes, John Hopkins University Press, Baltimore, MD.

De Waal, F., 2006, 'Morally evolved: Primate social instincts, human morality and the rise and fall of "veneer theory"', in S. Macedo \& J. Ober (eds.), Primates and philosophers: How morality evolved, pp. 1-80, Princeton University Press, Princeton, NJ.

De Waal, F., 2013, The bonobo and the atheist, Norton, New York.

Field, D.N., 2015a, 'The unrealised ethical potential of the Methodist theology of prevenient grace', HTS Teologiese Studies/Theological Studies 71(1), 1-8. https:// doi.org/10.4102/hts. v71i1.2987

Field, D.N., 2015b, 'Holiness, social justice and the mission of the church: John Wesley's insights in contemporary context', in Holiness. A Journal of Wesley House Cambridge 1(2), 177-198. http://www.wesley.cam.ac.uk/holiness/

Fuentes, A., 2009, Evolution of human behaviour, Oxford University Press, New York.

Goodall, J., 2010, Through a window: My thirty years with chimpanzees of Gombe, Houghton, Miffen Harcourt, New York.

Hill, M.N., 2016, Evolution and holiness: Sociobiology, altruism and Wesleyan perfection, InterVarsity Press, Downers Grove, IL.

Kärkkäinen, V.-M., 2015, Creation and humanity, constructive Christian theology for the pluralistic world, Eerdmans, Grand Rapids, MI.

Macedo, S. \& Ober, J. (eds.), 2016, Primates and philosophers: How morality evolved, Princeton University Press, Princeton, NJ.

Maddox, R.L., 1984, 'Responsible grace: The systematic perspective of Wesleyan theology', Wesleyan Theological Journal 19(2), 7-22.
Maddox, R.L., 2009, 'John Wesley's precedent for theological engagement with the natural sciences', Wesleyan Theological Journal 44(1), 23-54.

Morris, I., 2015, War! What is it good for? The role of conflict in civilisation from primates to robots, Profile Books, London.

Shreeve, J., 2015, 'This face changes the human story, but how?', National Geographic, 10 September, from http://news.nationalgeographic.com/2015/09/150910human-evolution-change; http://journals.plos.org/plosone/article?id=10.1371/ journal.pone.0126589

Thackeray, J.F., 2015, 'Estimating the age and affinities of Homo naledi', South African Journal of Science 111(11/12), Art. \#a0124. https://doi.org/10.17159/sajs.2015/ a0124

Van Huysteen, J.W., 2006, Alone in the world? Human uniqueness in science and theology, Vandenhoek and Ruprecht, Göttingen.

Wesley, J., 1984, The works of John Wesley, vol. 1, Sermons II, Bicentennial Edition, pp. 1-33, Abingdon Press, Nashville, TN.

Wesley, J., 1985, The works of John Wesley, vol. 2, Sermons II, Bicentennial Edition, pp. 34-70, Abingdon Press, Nashville, TN.

Wong, K., 2016, 'Debate erupts over strange new species: Skeptic challenges notion that small-brained Homo Naledi deliberately disposed of its dead', Scientific American, viewed 1 April 2017, from https://www.scientificamerican.com/article/ debate-erupts-over-strange-new-human-species/\#

Zollikofer, C.P.E., Ponce de León, M.S., Vandermeersch, B. \& Lévêque, F., 2002, 'Evidence for interpersonal violence in the St. Césaire Neanderthal', Proceedings of the National Academy of Sciences of the United States of America 99(9), 64446448. https://doi.org/10.1073/pnas.082111899 